\title{
Appraisal of Residential Real Estate Investment Diversification Prospects in South-South, Nigeria
}

\author{
Akpan, Kufre E. ${ }^{1} \quad$ Efekalam, Irene C. ${ }^{2^{*}}$ \\ Department of Estate Management, Abia State University, Uturu, Nigeria
}

\begin{abstract}
The study examined the diversification prospects of residential real estate investments in South-South, Nigeria. Data on residential real estate investment returns were obtained from 132 Estate Surveying and Valuation firms practicing in the region. 132 copies of questionnaire were used to obtain the primary data. The study covered the period between 2005 and 2019. Pearson Correlation was used in analyzing the relationship between residential real estate returns by property types across the region. The result revealed that a portfolio can be well diversified by combination of 5-bedroom maisonettes in Uyo and 5-bedroom maisonettes in Port Harcourt into one portfolio as they have a negative correlation. Also investing in 5-bedroom maisonettes in Uyo and 3-bedroom bungalows in Port Harcourt can produce a well-diversified portfolio as they have a negative correlation. This supports the conclusion that diversification by property types across places is better than diversification by property types within a place. It was recommended that investors should consider investing in different classes of residential properties across the region. This will help reduce their investment portfolio risk while maximizing their portfolio returns.
\end{abstract}

Keywords: Diversification, residential, real estate, investment, returns

DOI: $10.7176 / \mathrm{EJBM} / 13-24-09$

Publication date: December $31^{\text {st }} 2021$

\section{Introduction}

Recently the concept of diversification in real estate investment has become a topical issue. Investors are looking for better options to reduce their risk while maximising their returns. Portfolio diversification can thus be described as the technique of varying investment possibilities in order to minimise the encompassed risks and maximise the return from investments (Olaleye, 2011). The purpose of diversification is to have a balance between an acceptable level of risk and the expected return. In real estate investment practices, diversification has taken variant forms namely, diversification by geographic area, property type, life cycle, management type, ownership structure, and financial arrangement (Olaleye and Aluko, 2007). Diversification across regions and property types has the advantage of attracting the economic benefits of different regions to strength the portfolio returns and protecting the portfolio from the security risk which are bound at different locations. Since the concept of diversification was developed by Markowitz in 1952 and enhanced in 1959, the application of the theory has always been in use in analyzing portfolio risk and returns. The theory is primarily concerned with the degree of covariance between assets returns in a portfolio. It has shown that the opportunities for risk reduction in investment portfolios are negative functions of the correlations between assets returns (Eichholtz and Hoesli, 1995).

As Hoesli and MacGregor (2000) opined that real estate investment is a good store of wealth on the longterm basis, some investors following the crash in the capital market have indicated growing interest in property investment performance (Oyewole, 2006). This trend on investment thoughts has presented a good opportunity for Nigeria with the largest population in West Africa and a large housing market which has deficit of about 17 million housing unit (Ezema, Opoko, and Oluwatayo, 2017). In the last decade and a half, the property investment market has become dominated by major organisations and institutional investors and this has caused the pattern of investment in real estate in Nigeria to change substantially like in many parts of Africa and the world (Olaleye, 2011). Reasons presented to institutional investors for including property in their investment portfolios include low price volatility, high returns in relation to risk, potential for protection against inflation and deflation, stable rental revenue components, predictable components of operating expenses, and a low correlation with other assets, which allows for the diversification of the portfolio (Smietana, 2014). The development has also increased investors awareness and most of them are now treating their investments in property as a significant proportion of their total assets and are now demanding a higher degree of professional expertise from practitioners (Olaleye and Ajayi, 2004).

In order to satisfy the needs of the investors, some studies have been carried out in different parts of the world to advise investors on the best diversification strategies to adopt. Many of the studies have suggested diversification across regions and property types (Cheng and Roulac, 2007; Mueller 1993; Eichholtz and Hoesli, 1995; Miles and McCue, 1984; Olaleye and Ajayi, 2004). Unfortunately, in South-South region of Nigeria, there are few or no known studies carried out to explore how residential real estate investment portfolio can be constructed to take advantage of the different economic benefits across the region. Therefore this study is carried out with the aim of examining the diversification potentials of residential real estate investment in South-South region of Nigeria. 


\section{Study Area}

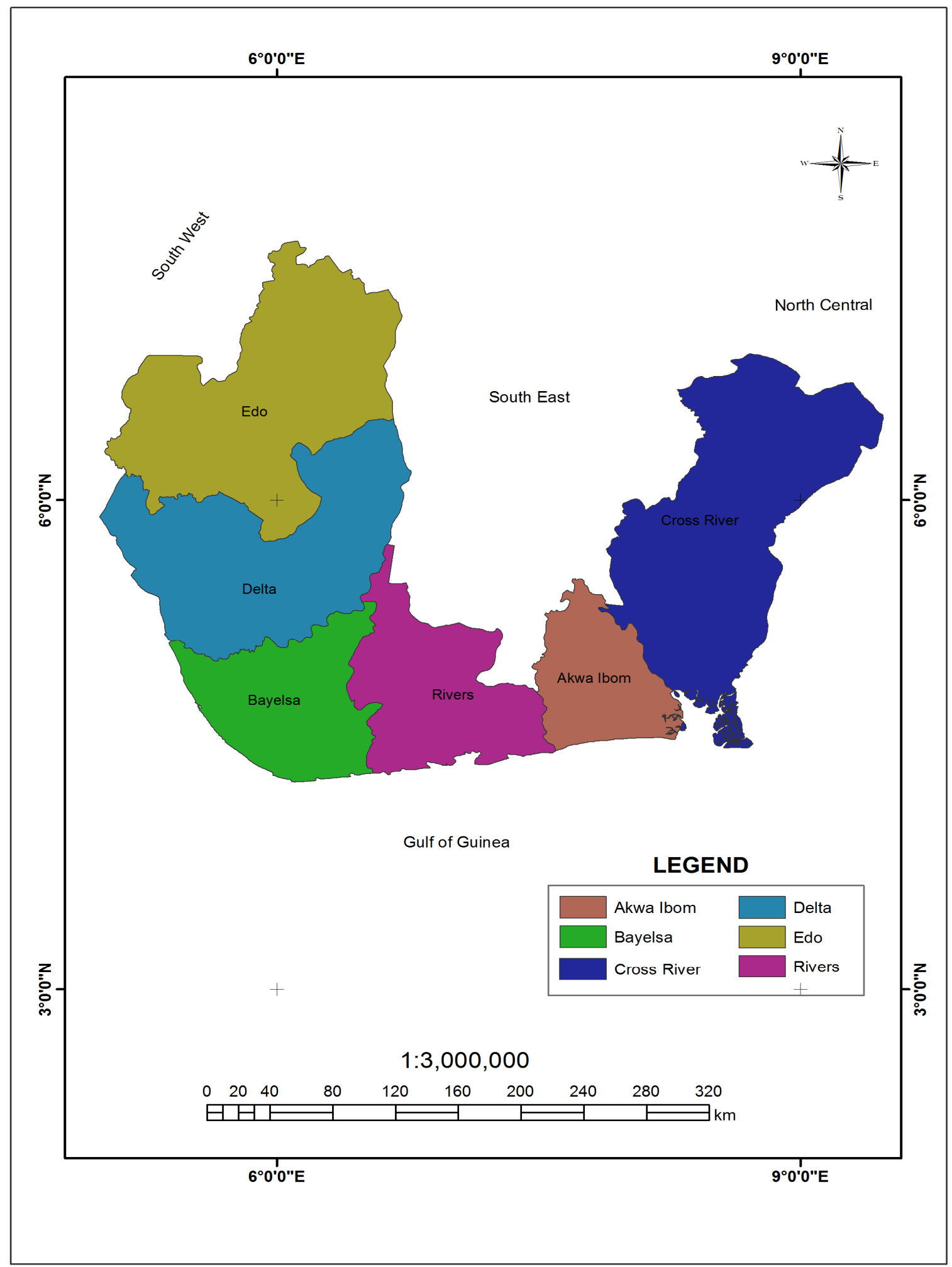

Fig 1: Map of South-South, Nigeria

South-South is one of the geo-political zones in Nigeria located in Southern part of Nigeria. It comprises six states- Akwa Ibom, Bayelsa, Cross River, Delta, Edo and Rivers. The area is dominated by the abundance of crude oil reserves, currently making the area popular and famous regarding natural resources in the country and the world at large (Omeje, 2006). The Niger Delta basin which is located in the region is considered the mainstay of the Nigerian economy for its significantly high level of oil reserves. The South-South region produces more than 80 
percent of total Nigerian crude oil which accounts for over $80 \%$ percent of the Federal Government revenue (Ebie, 2012). With this endowment, the region has attracted both Nigerians and foreigners to the region for oil exploration and exploitation activities.

The study focused on three state capitals in the region. These are Uyo in Akwa Ibom State, Calabar in Cross River State and Port Harcourt in Rivers State. The three cities were purposively chosen because of their proximity to one another to ease the study. These cities easily connected to one another by roads so it can ease the management of the investments by the investor as the investor can easily move from one city to the other to manage the investment. These urban areas have different socio-economic and institutional histories. For instance, Calabar is the first capital of Nigeria. Port Harcourt apart from being the state capital, is the administrative seat of some of the oil companies and also an industrial hub in the country. The oil activities in the region have attracted huge population into these cities and this has created huge opportunities for the development of many housing estates in this region, such as Ewet Housing Estate in Uyo, State Housing Estate in Calabar and Golf Estate in Port Harcourt and many other residential estates which has attracted huge rent of about N5 million per year for maisonettes. The products of the housing market in the region comprise tenement buildings, detached bungalows, semi-detached bungalows, blocks of flats, blocks of bed-sitting rooms or self-contained rooms and maisonettes. The housing products are developed in planned and unplanned districts in high, medium and low densities.

\section{Review of Related Literature}

Miles and McCue (1982) used a sample of real estate investment trusts (REITs) and regressed the return to risk ratio against variables representing the extent of diversification by property type and geographic region. They found evidence that diversification by property type produces higher risk-adjusted cash yields than geographic diversification.

Miles and McCue (1984) used property-specific data from a large commingled real estate fund. They found that correlations among returns on portfolios of properties differentiated by property type were significantly less than correlations among portfolios differentiated by region. Property type was a more efficient means of diversification.

Hartzell, Hekman and Miles (1986) conducted a study on diversification by geographic regions and divided the USA into regions of East, Mid-west, West and South. Appraisal-based data on properties for the period from 1973-1983 was used for the study. They found that correlations between returns in the four regions were usually low. They pointed, however, to the need for more detailed diversification categories.

Mueller (1993) examined efficient frontiers for various diversification schemes and compared them against naively diversified portfolios. The study found evidence to show that geographic and or property type diversification brings marginal improvement in portfolio performance.

Eichholtz and Hoesli (1995) examined real estate portfolio diversification by property type and region in USA and UK. They found that it was more effective to diversify across regions with a single property type or across property types within region.

Eichholtz, Koedijk, and De Roon (2002) examined the effect of residential property holdings on optimal investment portfolios in United States. The result showed that residential real estate contributes to significant diversification benefits relative to investments in stocks and bonds for US investors.

Adair, McGreal and Webb (2006) have demonstrated that diversification benefits may be captured by combining different classes of real estate assets in different locations or by acquiring different property types or using both strategies.

Hoesli and Lizieri (2007) observed that in practice, dispersion or spread of investment risk entails diversifying asset classes and types within various sectors and regions, separated administratively or geographically

Olaleye (2007) conducted study on diversification of real estate portfolio by managers and property type in Lagos. Property data were collected from 1997 to 2001. The study's analysis suggested that diversification of managers and property types produce improved performance.

Umeh (2015) analyzed the diversification potentials of residential property investments by local areas in Ibadan. The study concluded that risk of return due to diversification varies across property types and geographic locations in the study areas.

Geurts and Jaffe (1996) concluded that the prospects for institutional characteristics suggest for risk reduction in internationally diversified portfolios and the risk/return relationship of each country is affected by its own unique institutional environment and therefore are potential benefits to the investors.

Mueller and Ziering (1992) analyzed real estate portfolio combination of economic and geographic diversifications and concluded that there are risk-reduction benefits when the returns on assets are not correlated with each other.

Hartzell, Shulman and Wurtzebach (1987) took a closer look at criteria for regional diversification of real estate and concluded that a well-diversified portfolio should consist of assets from geographic regions with different economic characteristics. 


\section{Research Methodology}

This study employed the use of correlational-research design to examine the relationship between the returns of the various classes of residential real estate investments in the region from 2005 to 2019. 132 copies of questionnaire were administered to firms of Estate Surveyors and Valuers to collect data for the computation of the returns on residential real estate investment. Five (5) properties were randomly sampled in each category of the properties under the study (2-bedroom flats, 3 - bedroom bungalows and 5-bedroom maisonnettes) from the management portfolios of the 132 Estate Surveyors and Valuers firms. Pearson Correlation analysis was used to analyze the correlation among the returns of the various residential properties in the study area. The correlation coefficient was used to ascertain the strength of the relationship among the different classes of assets across the region.

\section{Data presentation and analysis}

Table 1: Correlation analysis of residential real estate returns in South-South, Nigeria

\begin{tabular}{|c|c|c|c|c|c|c|c|c|}
\hline $\begin{array}{c}\text { 3-B/R } \\
\text { Bungalow } \\
\text { Calabar }\end{array}$ & $\begin{array}{c}3 \mathrm{~B} / \mathrm{R} \\
\text { Bungalow- } \\
\text { Port } \\
\text { Harcourt }\end{array}$ & $\begin{array}{c}\text { 3-B/R } \\
\text { Bungalow- } \\
\text { Uyo }\end{array}$ & $\begin{array}{c}\text { 2-B/R } \\
\text { Flat- } \\
\text { Calabar }\end{array}$ & $\begin{array}{l}2 \quad \text { B/R } \\
\text { Flat-Port } \\
\text { Harcourt }\end{array}$ & $\begin{array}{c}2 \\
\text { B/R } \\
\text { Flat- } \\
\text { Uy0 }\end{array}$ & $\begin{array}{c}\text { 5-B/R } \\
\text { Mainsonette- } \\
\text { Calabar }\end{array}$ & $\begin{array}{c}\text { 5-B/R } \\
\text { Maisonette- } \\
\text { Port } \\
\text { Harcourt }\end{array}$ & $\begin{array}{c}\text { 5-B/R } \\
\text { Maisonette- } \\
\text { Uyo }\end{array}$ \\
\hline
\end{tabular}

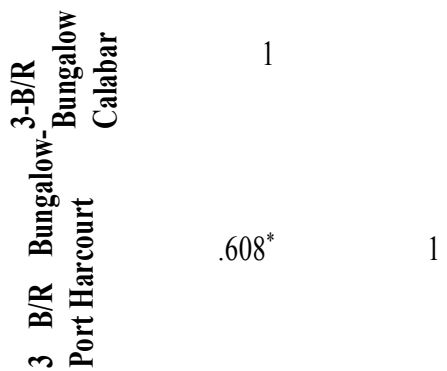

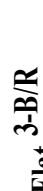

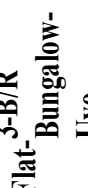

$.744^{* *} \quad .524^{*} \quad 1$

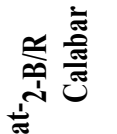

0.399

$.596^{*}$

0.476

1

究

(a)

$.880^{* *}$

0.513

$.800^{* *}$

0.463

1

竞

$\stackrel{\sim}{\sim} \frac{1}{5}$

$.621^{*}$

0.462

$.775^{* *}$

$.641^{* *}$

$.675^{* *} \quad 1$

象.

尊

竞

$.878^{* *}$

$.592^{*}$

0.368

$.563^{*} \quad 0.405$

0.23

1

*. Correlation is significant at the 0.05 level (2-tailed).

$* *$. Correlation is significant at the $\mathbf{0 . 0 1}$ level (2-tailed).

Table 1 shows the returns from 3-bedroom bungalows in Uyo, Calabar and Port Harcourt. From the 
correlation coefficient in Table 1, the best diversification option is to invest in 5-bedroom maisonnettes in Uyo and Port Harcourt as their combination has negative correlation coefficient of -0.22 . This implies that their returns do not move in the same direction. This means that the factors that affect 5-bedroom maisonnettes in Uyo are not the same factors that affect 5-bedroom maisonnettes in Port Harcourt. Based on this, the investor can take advantage of the returns on the investment at one geographic location to cushion the effect of the low returns at the other location when some factors will affect it. Based on the analysis in Table 1, the worst diversification option is to combine 5-bedroom maisonnettes in Calabar and 2-bedroom flats in Calabar as they have the highest positive correlation coefficient of 0.959 . This implies that the returns from the two properties move in the same direction with a very strong relationship. This means that the factors which affect one of the properties strongly affects the other.

From Table 1, assuming an investor wants to invest only in 3-bedroom bungalows across the geographic locations of South-South, Nigeria, a combination of 3-bedroom bungalows in Uyo and Port Harcourt may be better as they have correlation coefficient of 0.524 than combining 3-bedroom bungalows in Uyo and Calabar or Port Harcourt and Calabar which have correlation coefficient of 0.744 and 0.608 respectively. Though all of them have positive coefficient which means their returns move in the same direction but combination of 3-bedroom bungalows in Uyo and Port Harcourt have the least positive coefficient amongst them while combination of 3bedroom bungalows in Uyo and Calabar is the worst as they have the highest positive correlation.

From Table 1, assuming an investor wants to invest only in 2-bedroom flats across the geographic locations of South-South, Nigeria, a combination of 2-bedroom flats in Calabar and Port Harcourt may be better as they have correlation coefficient of 0.463, than combining 2-bedroom flats in Uyo and Calabar or Port Harcourt and Uyo which have correlation coefficients of 0.641

and 0.675 respectively. Though all of them have positive coefficient which means their returns move in the same direction but combination of2-bedroom flats in Calabar and Port Harcourt has the least positive coefficient amongst them while combination of 2-bedroom flats in Uyo and Port Harcourt is the worst as they have the highest positive correlation.

Based on Table 1, assuming an investor wants to invest only in 5-bedroom maisonettes across the geographic locations of South-South, Nigeria, a combination of 5-bedroom maisonettes in Uyo and Port Harcourt may be better as they have correlation coefficient of -0.22, than combining 5-bedroom maisonettes in Uyo and Calabar or Port Harcourt and Calabar which have correlation coefficient of 0.43 and 0.23 respectively. Combination of 5bedroom maisonettesin Uyo and Port Harcourt has a negative coefficient. This implies that their returns do not move in the same direction. This means that the factors that affect 5-bedroom maisonettes in Uyo are not the same factors that affect 5-bedroom maisonettes in Port Harcourt. The worst combination in the category of 5-bedroom maisonnettes is Uyo and Calabar as they have the highest positive correlation.

\section{Conclusion}

From the analysis of the returns on investments in residential real estate investments in South-South, Nigeria, a portfolio can be well diversified by combination of 5-bedroom maisonettes in Uyo and 5-bedroom maisonettes in Port Harcourt into one portfolio as they have a negative correlation. Also investing in 5-bedroom maisonettes in Uyo and 3-bedroom bungalows in Port Harcourt can produce a well-diversified portfolio as they have a negative correlation. This supports the conclusion that diversification by property types across places is better than diversification by property type within a place. This conclusion is in line with the conclusion of Adair et al (2006). This conclusion is also supported by the position of Hartzell et al (1987) who stated that a well-diversified portfolio should consist of assets from geographic regions with different economic characteristics. We therefore recommend that institutional real estate investors should consider investing in different classes of residential properties across the regions which have different economic characteristics.

\section{References}

Adair, A., McGreal, S. \& Webb, J. R. (2006). Diversification Effects of Direct versus Indirect Real Estate Investments in the U.K. Journal of Real Estate Portfolio Management, 12(2), 85-90.

Cheng, P. \&Roulac, S. (2007). Measuring the effectiveness of geographical diversification .Journal of Real Estate Portfolio Management,13 (1).

Ebie, S. (2012). The imperative of social housing in the South-South Region of Nigeria. Journal of the Nigerian Institution of Estate Surveyors and Valuers, 37(1), 56-70.

Eichholtz, P. M. A, \&Hoesli, M. (1995). Real estate portfolio diversification by property type and region. Journal of Property Finance, 6 (3), 39-59.

Eichholtz, P.M.A., Koedijk, K.G. \& De Roon, F.A. (2002). The portfolio implications of homeownership. Working paper, Maastricht University, Maastricht and University ofAmsterdam, Amsterdam.

Ezema, I., Opoko, A. \&Oluwatayo, A. (2017). Bridging the housing deficit in Nigeria: Energy and $\mathrm{CO}_{2}$ emission implications. Journal of Sustainable Human Settlement and Housing, 1(1), 27-40. 
Guerts, T. G. \& Jaffe, A. J. (1996). Risk and real estate investment: An international perspective. Journal of Real Estate Research, 2(2), $117-130$.

Hartzell, D. J., Hekman, J. S. \& Miles, M. E. (1986). Diversification Categories in Investment Real Estate. AREUEA Journal, 14(2), 230-254.

Hartzell, D. J., Shulman, D. G. \&Wurtzebach, C. H. (1987). Refining the analysis of regional diversification for income-producing real estate. Journal of Real Estate Research, 2(2), 85 - 95.

Hoesli, M. \&Lizieri, C., (2007). Real estate in the investment portfolio. Report to the InvestmentStrategy Council of the Norwegian Ministry of Finance, http://centaur.reading.ac.uk/view/creators/90002838.html

Hoesli, M. \& Macgregor, B. D. (2000). Property Investment: Principles and Practice of Portfolio Management. England, Pearson Education Limited.

Miles, M. \& McCue, T. (1984). Commercial real estate returns. AREUEA Journal, 12(3),55-77.

Miles, M. E. \& McCue, T. E. (1982). Historic Returns and Institutional Real Estate Portfolio.AREUEA Journal, 10(2), 184-198.

Mueller, G. R. (1993). Refining economic diversification strategies for real estate portfolios. Journal of Real Estate Research, 8(1), 55-68.

Mueller, G. R. \& Ziering, B. A. (1992). Real estate portfolio diversification using economic diversification. Journal of Real Estate Research, 7(4), 375 - 386.

Olaleye, A. \& Aluko, B.T. (2007). Evaluating manager's diversification of real estate portfolios: Evidence from Nigeria. International Journal of Strategic Property Management, 11(3), 179-189.

Olaleye, A. (2011). Property portfolio diversification strategies: A review of the options. Ife Journal of Environmental Design and Management, 5(1), 15 - 30.

Olaleye, A. \& Ajayi, C. A. (2004). Towards a macro approach to the management of property portfolio in Nigeria. Journal of Property Research and Construction, 1(1), 70-82.

Omeje, K. C. (2006). High stakes and stakeholders: Oil conflict and security in Nigeria: Ashgate Publishing, Ltd.

Oyewole, M. O. (2006). A Comparative Study of the Performance of Direct and Indirect Property Investment in Lagos. An unpublished M.Sc. Dissertation of the Department of Estate Management, Obafemi Awolowo University, Ile-Ife.

Rees, P. \&Kestel, S. (2014). Analysis of portfolio diversification between REIT assets. Journal of Computational and Applied Mathematics 259, 425-433.

Smietana, K. (2014). Diversification principles of real estate portfolios. Journal of Real Estate Management and Valuation, 22(1), $54-60$.

Umeh, O. L. (2015). Diversification potentials of residential property investments by local areas in Ibadan. Journal of the Environment, 9(1), $68-77$.

\section{Acknowledgements}

Our sincere appreciation goes to Abia State University, Uturu, Abia State, Nigeria for giving us the opportunity to carry out this research. Special thanks are given to Professor A. I. Kalu and Professor M. U. Eze for their professional guidance, attention, support and encouragement towards the completion of this research. Finally, we appreciate the supports from everyone who has assisted us to successfully complete this research especially to those authors whose work were referenced and used. 